Original Research

\title{
UJI AKTIVITAS ANTIBAKTERI FRAKSI BUTANOL, ETIL ASETAT, DAN n-HEKSAN DAUN BINAHONG (Anredera cordifolia (Ten.) Stennis) TERHADAP BAKTERI Propionibacterium acnes ATCC 37533 SECARA IN VITRO
}

\author{
ANTIBACTERIAL ACTIVITY TEST OF BUTANOL FRACTION, ETHYL \\ ACETATE, AND n-HEXANE BINAHONG LEAVES (Anredera cordifolia (Ten.) \\ Stennis) BACTERIA OF Propionibacterium acnes ATCC 37533 IN VITRO
}

\author{
Algren Ruben Awirana ${ }^{l,}$ Sutriningsih ${ }^{2 *}$ \\ Fakultas Farmasi, Universitas 17 Agustus 1945 Jakarta, Jakarta Utara, Indonesia, 14350. \\ *Email: vinnelaras@yahoo.co.id
}

\begin{abstract}
Abstrak
Salah satu tanaman yang berkhasiat sebagai antibakteri adalah binahong. Kandungan senyawa dari daun binahong adalah flavonoid (8-Glukopyranosyl-4', 5,7-trihydroxyflavone) dan steroid (Stigmasterol). Tujuan dari penelitian ini untuk melihat fraksi butanol, etil asetat dan n-heksan daun binahong (Anredera cordifolia (Ten.) Steenis) yang dapat menghambat pertumbuhan bakteri Propionibacterium acnes. Uji aktivitas antibakteri menggunakan metode difusi cakram dengan variasi konsentrasi 200, 100, 50, 25, dan 12,5 mg/mL serta klindamisin sebagai kontrol positif. Uji aktivitas antibakteri menunjukkan bahwa fraksi yang paling aktif dari daun binahong (Anredera cordifolia (Ten.) Steenis) yang dapat menghambat pertumbuhan bakteri Propionibacterium acnes adalah fraksi n-heksan pada konsentasi $200 \mathrm{mg} / \mathrm{mL}$ dengan zona hambat sebesar $14.99 \mathrm{~mm}$, diikuti dengan fraksi etil asetat sebesar $12.68 \mathrm{~mm}$ dan fraksi butanol sebesar $8.88 \mathrm{~mm}$.
\end{abstract}

Kata Kunci: Daun Binahong (Anredera cordifolia (Ten.) stennis) Propionibacteriumn acnes, Difusi cakram

\begin{abstract}
One of the antibacterial plan is binahong. The compound content of binahong leaf is flavonoid (8Glukopyranosiyl-4', 5,7 tryhydroxyflavone) and steroid (Stigmasterol). The purpose of this research is to know if butanol, etil asetat and n-hexane fraction of binahong leaf (Anredera cordifolia (Ten.) Stennis) can inhibit the growth of Propionibacterium acnes. The antibacterial activity test was done by using disc diffusion method with variety of concentrations of $200,100,50,25$, and $12,5 \mathrm{mg} / \mathrm{mL}$ and clindamycin as control positif. The antibacterial activity test showed that most active fraction of binahong leaves that can inhibit the growth of Propionibacterium acnes was the n-hexane fraction at a concentration $200 \mathrm{mg} / \mathrm{mL}$ with an average inhibition zone $14.99 \mathrm{~mm}$, followed by ethyl acetate fraction $12.68 \mathrm{~mm}$, and butanol fraction $8.88 \mathrm{~mm}$.
\end{abstract}

Keywords: Binahong Leaves (Anredera cordifolia (Ten.) Stennis), Propionibacteriumn acnes, Disc Diffusion 


\section{PENDAHULUAN}

Acnes vulgaris atau jerawat adalah kelainan kulit kronis yang menyebabkan peradangan akibat produksi spesies oksigen yang reaktif karena keterlibatan bakteri Propionibacterium acnes yang terjadi infeksi pada lokasi kulit [1]. Jerawat juga merupakan salah satu penyakit kulit yang paling umum di dunia yang mempengaruhi semua kelompok etnis dan usia, jerawat biasanya terjadi dikalangan remaja tanpa memandang jenis kelamin, kebangsaan, atau status sosial dan ekonomi [2].

Tanaman binahong merupakan salah satu tanaman obat yang mempunyai potensi besar ke depan untuk diteliti, dan dapat dikembangkan sebagai salah satu alternatif dalam pengobatan. Berbagai pengalaman masyarakat, daun binahong dapat dimanfaatkan untuk membantu proses penyembuhan penyakit seperti mengobati diabetes militus, tifus, hipertensi, wasir, tuberculosis, asam urat, asma, meningkatkan volume urine untuk diuretik, penyembuhan luka, diare, gastritis, dan kanker [3], sebagai antioksidan [4] antibiotik, antibakteri, antivirus, dan antiinflamasi [5]. Hasil skrining fitokimia daun binahong mengandung senyawa flavonoid senyawa steroid dan saponin [6]. Dan pada penelitian sebelumnya daun binahong diduga mengandung senyawa flavonoid golongan jenis 8glukopiranosil-4'6,7 Trihidroksiflavon [7], dan senyawa steroid jenis stigmasterol [8]. Dari hasil penelitian yang dilakukan oleh [9] dalam isolasi dan uji aktivitas antibakteri daun binahong menunjukan bahwa diameter daerah hambat ekstrak daun binahong dapat menghambat pertumbuhan bakteri $E$. coli dan $S$. aures. Hal ini karena diduga adanya senyawa flavonoid golongan auron dalam daun binahong yang dapat menghambat pertumbuhan bakteri. Dari hasil penelitian diatas maka dapat dikatakan esktrak daun binahong mempunyai bioaktivitas sebagai anti bakteri.

Berdasarkan latar belakang tersebut, peneliti tertarik untuk melakukan pengujian lebih lanjut untuk meneliti pada fraksi mana daun binahong yang memiliki aktivitas antibakteri paling baik dalam menghambat pertumbuhan bakteri Propionibacterium acnes.

\section{METODE}

\section{Sampel (Bahan) Penelitian}

Daun Binahong (Bogor, Kopo Cisarua), aquadest (Brataco), etanol $96 \%$ (Brataco), n-heksan (Merck, Damstardt, Germany) dan etil asetat (Merck, Damstardt, Germany), butanol (Merck, Damstardt, Germany), media Mueller Hinton Agar, media Nutrient Agar, dan darah domba steril.

\section{Prosedur Kerja}

Proses pengolahan daun Binahong dimulai dari pemilihan daun yang sudah memasuki periode matang dari segi usia panen, yaitu daun binahong yang cukup tua, minimal berumur 10 bulan dengan ciri-ciri warna daun mengkilat dan licin. Daun binahong yang segar dicuci dan dibersihkan dari pengotornya, kemudian dikeringkan dengan cara diangin-anginkan. Setelah kering, simplisia digiling dan diayak dengan pengayak ukuran 40 mesh hingga menjadi serbuk. Selanjutnya serbuk simplisia diekstraksi dengan metode maserasi 
menggunakan etanol 96\% selama 3x24 jam, diaduk dan dibiarkan dalam bejana tertutup, kemudian disaring dan diambil filtratnya. Selanjutnya filtratnya dipekatkan dengan menggunakan rotary vaccum evaporator hingga diperoleh ekstrak kental [10].

\section{Fraksinasi}

Ekstrak daun binahong yang didapat ditimbang sebanyak 30 gram dilarutkan dengan aquadest sebanyak $90 \mathrm{~mL}$ dan kemudian difraksinasi dengan pelarut n-heksan $90 \mathrm{~mL}$, dipisahkan lapisan n-heksan dengan cara dituang dari corong pisah ke erlenmeyer, lakukan pengulangan hingga kira-kira senyawa yang ingin ditarik sudah tertarik sempurna, selanjutnya fraksi dipekatkan di atas penangas air.

Ekstrak daun binahong yang telah disari dengan n-heksan dilanjutkan disari dengan etil asetat $90 \mathrm{~mL}$, dimasukan etil asetat dengan cara dituang dari corong pisah ke erlenmeyer, lakukan pengulanggan dengan jumlah pelarut yang sama hingga kira-kira semua senyawa yang ingin ditarik sudah tertarik sempurna. Hasilnya diperoleh fraksi etil asetat.Ekstrak hasil fraksinasi dipekatkan dengan penangas air.

Ekstrak daun binahong yang telah disari dengan etil asetat dilanjutkan disari dengan pelarut butanol $90 \mathrm{~mL}$, kemudian dimasukan butanol dengan cara dituang dari corong pisah ke erlenmeyer, lakukan pengulanggan dengan jumlah pelarut yang sama hingga kira-kira semua senyawa yang ingin ditarik sudah tertarik sempurna. Hasilnya diperoleh fraksi butanol.Ekstrak hasil fraksinasi dipekatkan dengan penangas air.

\section{Uji Aktivitas Antibakteri}

Bakteri Propionibacterium acnes yang telah disuspensi sebelumnya sebanyak 1-2 ose dari biakan murni bakteri dengan menggunakan $\mathrm{NaCl} 0,9 \%$ sesuai dengan standar $M c$ Farland $\left(1 \times 10^{5} \mathrm{CFU} / \mathrm{mL}\right)$ kemudian disebar diatas media agar darah dengan menggunakan kapas lidi steril (cotton bud steril) atau batang L dengan variasi konsentrasi $200 \mathrm{mg} / \mathrm{mL}, 100$ $\mathrm{mg} / \mathrm{mL}, 50 \mathrm{mg} / \mathrm{mL}, 25 \mathrm{mg} / \mathrm{mL}, 12,5 \mathrm{mg} / \mathrm{mL}$.

Pengujian dilakukan dengan cara menggunakan kertas cakram yang sudah diteteskan ekstrak daun binahong dengan berbagai konsentrasi dengan menggunakan mikro pipet. Untuk kontrol negatif digunakan DMSO $10 \%$ (dimetil sulfoksida) dan antibiotik klindamisin sebagai kontrol positifnya, kemudian ditempelkan pada permukaan media agar darah yang telah dioleskan dengan bakteri. Selanjutnya masukan media tersebut kedalam inkubator dengan suhu $37^{\circ} \mathrm{C}$ selama $48 \mathrm{jam}$. Setelah itu dilakukan pengukuran diameter zona hambat dengan menggunakan jangka sorong. Pengujian ini dilakukan sebanyak 3 kali pengulangan. 


\section{HASIL DAN PEMBAHASAN}

\section{Hasil ekstrasi daun Binahong}

Pembuatan ekstrak daun binahong dilakukan dengan metode maserasi dengan pelarut etanol 96\%. Metode maserasi adalah metode yang paling sering digunakan untuk mengekstrak jaringan tumbuhan dan proses yang paling sederhana. Hasil ekstrak etanol 96\% daun binahong seesar 173,33 gram dengan rendamen sebesar 13,38\%.

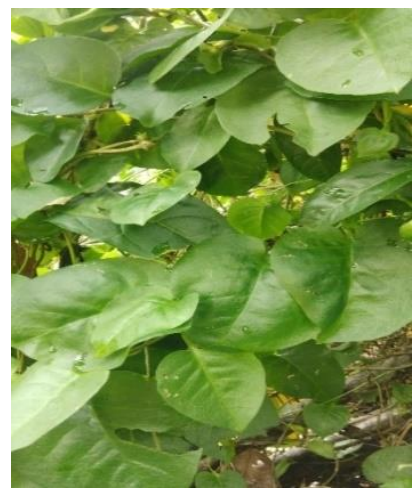

$\mathrm{a}$

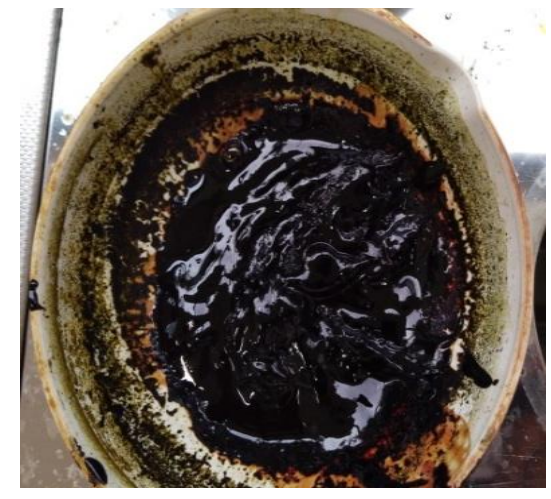

b

Gambar 1. (a) Daun Binahong (b) Hasil Ekstrak Etanol 96\% Daun Binahong.

\section{Fraksinasi Daun Binahong}

Fraksinasi binahong dilakukan secara bertahap-tahap dengan tujuan supaya hasil yang didapat maksimal, fraksinasi sendiri adalah proses penarikan senyawa pada suatu ekstrak dengan menggunakan dua macam pelarut yang saling tidak bercampur tujuannya untuk mengambil senyawa aktif sesuai dengan kepolaranya. Proses fraksinasi menggunakan pelarut n-heksan (nonpolar), etil asetat (semipolar), dan butanol (polar). Berat fraksi kental yang didapatkan dari 30 gram ekstrak etanol 96\% daun binahong adalah fraksi n-Heksan 6,32 gram dengan rendamen 10,53\%, fraksi etil asetat 3,78 gram dengan rendamen 6,3\% dan fraksi butanol 3,55 gram dengan rendamen 5,91\%.

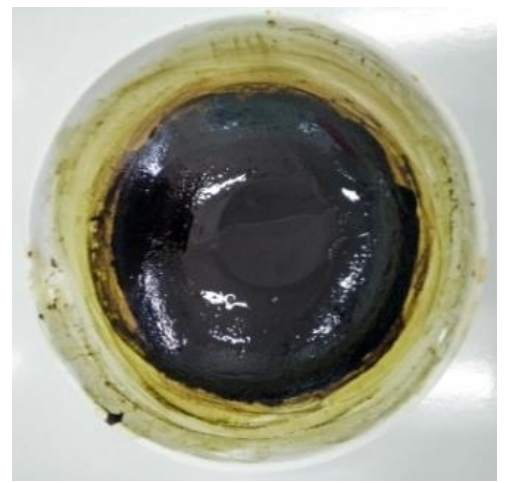

a

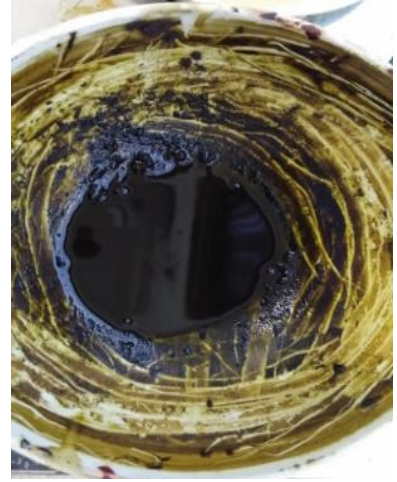

b

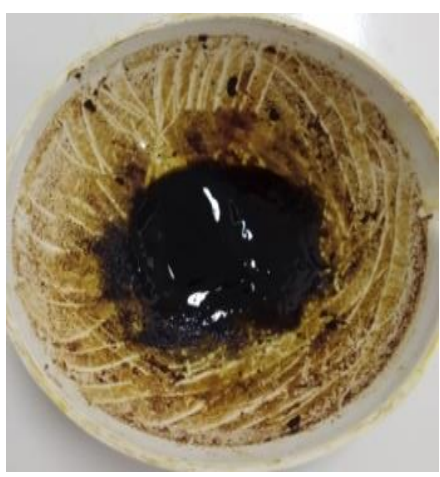

$\mathrm{c}$

Gambar 2. (a) Hasil Fraksi N-heksan (b) Hasil Fraksi Etil Asetat (c) Hasil Fraksi Butanol 


\section{Aktivitas Antibakteri}

Tabel 1. Hasil Pengujian Aktivitas Antibakteri Fraksi N-Heksan, Fraksi Etil-Asetat Dan Fraksi Butanol Daun Binahong (Anredera cordiafolia (Ten.) Stennis Terhadap Bakteri Propionibacterium acnes.

\begin{tabular}{|c|c|c|c|c|c|}
\hline \multirow{2}{*}{ Fraksi Uji } & \multirow{2}{*}{$\begin{array}{c}\text { Konsentrasi } \\
(\mathbf{m g} / \mathbf{m L})\end{array}$} & \multicolumn{3}{|c|}{$\begin{array}{c}\text { Diameter Daya Hambat } \\
(\mathbf{m m})\end{array}$} & \multirow{2}{*}{$\begin{array}{c}\text { Rata-rata } \\
\text { diameter } \\
(\mathbf{m m})\end{array}$} \\
\hline & & I & II & III & \\
\hline \multirow{7}{*}{ n-Heksan4 } & 200 & 15,32 & 14,79 & 14,86 & 14,99 \\
\hline & 100 & 14,63 & 11,35 & 11,81 & 12,59 \\
\hline & 50 & 13,35 & 9,29 & 10,12 & 10,92 \\
\hline & 25 & 9,97 & 8,26 & 9,89 & 9,37 \\
\hline & 12,5 & 6 & 7,42 & 7,91 & 7,11 \\
\hline & KKP & 28,23 & 27,89 & 26,78 & 27,63 \\
\hline & KKN & 6 & 6 & 6 & 6 \\
\hline \multirow{7}{*}{ Etil Asetat } & 200 & 14,05 & 10,11 & 13,89 & 12,68 \\
\hline & 100 & 12,35 & 9,15 & 12,23 & 11,24 \\
\hline & 50 & 10,98 & 7,34 & 9,38 & 9,23 \\
\hline & 25 & 8,57 & 6 & 8,13 & 7,27 \\
\hline & 12,5 & 7,23 & 6 & 6,59 & 6,95 \\
\hline & KKP & 27,68 & 26,20 & 28,18 & 27,35 \\
\hline & $\mathrm{KKN}$ & 6 & 6 & 6 & 6 \\
\hline \multirow{7}{*}{ Butanol } & 200 & 9,12 & 8,74 & 8,14 & 8,88 \\
\hline & 100 & 7,12 & 6 & 6 & 6,37 \\
\hline & 50 & 6 & 6 & 6 & 6 \\
\hline & 25 & 6 & 6 & 6 & 6 \\
\hline & 12,5 & 6 & 6 & 6 & 6 \\
\hline & KKP & 27,51 & 26,33 & 26,01 & 26,61 \\
\hline & KKN & 6 & 6 & 6 & 6 \\
\hline
\end{tabular}

Keterangan :

KKP : (Kelompok kontrol Positif) : Klindamicin disk $(2 \mu \mathrm{L})$

KKN : (Kelompok kontrol Negatif) : DMSO 10\%. 


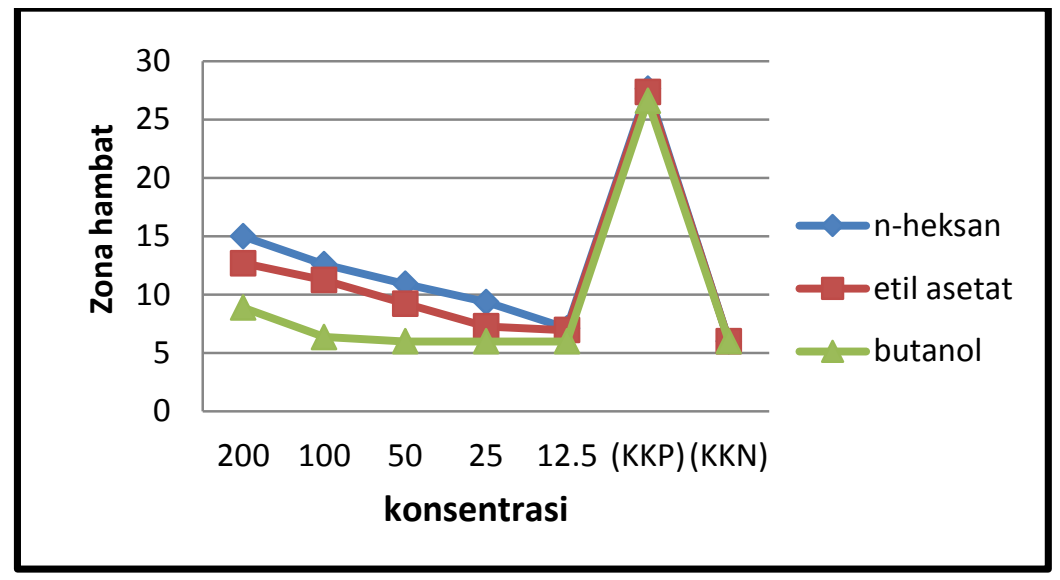

Gambar 3 Grafik Rata-Rata Diameter Zona Hambat Fraksi n-Heksan, fraksi Etilasetat dan Fraksi Butanol

Hasil uji aktivitas antibakteri dilakukan untuk mengetahui aktivitas antibakteri ekstrak daun binahong terhadap pertumbuhan bakteri Propionibacterium acnes. Metode yang digunakan pada penelitian ini adalah metode difusi cakram. Pada hasil uji aktivitas menunjukan bahwa kontrol positif yaitu Klindamisin sangat menghambat pertumbuhan bakteri Propionibacterium acnes dimana zona hambat rata-rata pada kontrol positif untuk fraksi n-heksan adalah 27,63 mm fraksi etil-asetat 27,35 mm dan untuk fraksi butanol 26,61 mm, sedangkan untuk kontrol negatif menggunakan DMSO 10\% menunjukan bahwa tidak adanya zona hambat yeng terbentuk disekitar kertas cakram.

Dari hasil data yang diperoleh menunjukan bahwa adanya zona hambat fraksi n-heksan, fraksi etil-asetat dan fraksi butanol daun binahong (Anredera cordifolia (Ten.) Steenis) dengan menggunakan 5 konsentrasi yaitu $200 \mathrm{mg} / \mathrm{mL}, 100 \mathrm{mg} / \mathrm{mL}, 50 \mathrm{mg} / \mathrm{mL}, 25 \mathrm{mg} / \mathrm{mL}, 25$ $\mathrm{mg} / \mathrm{mL}, 12,5 \mathrm{mg} / \mathrm{mL}$. Hasil yang diperoleh dari ketiga fraksi yang didapat dimana zona hambat terbesar dari bakteri Propionibacterium acnes adalah fraksi n-heksan dengan konsetrasi rata-ratanya adalah pada konstrasi $200 \mathrm{mg} / \mathrm{mL}$ dan rata-rata zona hambat yaitu 14,99 mm, jika mengacu pada tabel diameter zona hambat dapat dinyatakan bahwa hasil diameter yang diperoleh dari fraksi n-heksan masuk pada kategori kuat dengan kata lain dapat menghambat pertumbuhan bakteri Propionibacterium acnes, sedangkan pada fraksi butanol pada konsentrasi $50 \mathrm{mg} / \mathrm{mL}, 25 \mathrm{mg} / \mathrm{mL}$ dan $12,5 \mathrm{mg} / \mathrm{mL}$ tidak terbentuk adanya zona hambat hal ini menunjukan pada fraksi butanol tidak menghambat pertumbuhan bakteri. Perbedaan diameter zona hambat masing-masing konsentrasi disebabkan oleh besarnya zat aktif yang terkandung pada konsentrasi tersebut. Dimana semakin besar konsentrasi, maka semakin besar pula komponen zat aktif yang terkandung didalamnya sehingga zona hambat yang terbentuk juga berbeda pada konsentrasi. 


\section{KESIMPULAN}

Fraksi n-heksan, fraksi etil-asetat dan butanol daun binahong (Anredera cordifolia (Ten.) Stennis) memiliki aktivitas antibakteri terhadap bakteri Propionibacterium acnes. Hasil uji aktivitas anti bakteri pada fraksi n-heksan paling aktif dalam menghambat pertumbuhan bakteri Propionibacterium acnes pada konsentrasi $200 \mathrm{mg} / \mathrm{mL}$ dengan rata-rata diameter $14.99 \mathrm{~mm}$ dan termasuk dalam kategori kuat.

6

\section{DAFTAR PUSTAKA}

1. Sharma, R., Navneet, K., Ahmed, H., \& Namrita, L., (2013). Antibacterial and AntiInflammatory effects of Syzygium jambos L. (Alston) and Isolated Compounds on Acne Vulgaris. Journal BMC Complementary \& Alternative Medicine. Vol 13 (292).

2. Zouboulis, C, C., Eadi, A., Philpott, M., Goldsmith, A, L., Orfanos, C., Cunliffe, W, C., \& Rosenfield, R., (2005). What is the Pathogenesis of acne?. Denmark: Journal Experimental Dermatologi. Vol 14 (143-152).

3. Manoi, F. dan Balitro (2009). Binahong (Anredera cordifolia) sebagai obat. Warta Penelitian dan Pengembangan Tanaman Industri. Bogor: Vol 15 (1): 3-5

4. Selawa, W., M. R. J. Runtuwene., \& Citraningtyas, G., (2013). Kandungan flavonoid dan kapasitas antioksidan total ekstrak etanol daun binahong (Anredera cordifolia (Ten.) Steenis.). Journal Ilmiah Farmasi. Vol 2 (1): 18-22.

5. Kurniawan, B. \& W,F, Aryana. (2015). Binahong (Casia alata L) as Inhibitor Eschericia coli Growth, Lampung: Journal Majoritty. Vol 4 (4).

6. Garmanaa, A, N., Sukandara, E, Y., \& Fidriannya, I., (2014). Activity of several plant extracts against drug-sensitive and drug-resistant microbes. Bandung: Journal International Seminar on Natural Product Medicines, Proc. Chem 13: 164 - 169.

7. Djamil, R., Winarti, W., Sarah, Z., \& Syamsudin, A., (2017) Antidiabetic Activity of Flavanoid From Binahong Leaves (Anredera cordifolia) Extract in Alloxan Indiced Mice. Jakarta: Journal of Pharmacognosi \& Natural Products. Vol 3 (2).

8. Manik, Y., Enny, F., \& Dewi, K., (2013). Isolasi, Identifikasi dan uji sitotoksik senyawa steroid dari daun binahong (Anredera cordifolia (Ten) Steenis). Semarang: Journal of Scientific and Applied Chemistry. Vol 16 (1) 23-26.

9. Veronita, F., Nanik, W., \& Sri, M., (2017) Isolasi Dan Uji aktivitas Antibakteri Daun Binahong Serta Aplikasinya Sebagai Hand Sanitiser.Indonesian: Journal of Chemical Scine, Vol 6 (2) 142 .

10. Departemen Kesehatan Republik Indonesia 2000 Parameter Standar Umum Ekstrak Tumbuhan Obat. Jakarta: Direktorat Jenderal Pengawasan Obat dan Makanan. Hal 9-11,16.5. 